\title{
Failure of indomethacin to close persistent ductus arteriosus in infants weighing under 1000 grams
}

\author{
HALLAM H. IVEY, JOHN KATTWINKEL, TONG S. PARK, AND \\ L. JEROME KROVETZ \\ From the Department of Pediatrics, Divisions of Neonatology and Cardiology, University of Virginia \\ Medical Center, Charlottesville, Virginia, USA
}

SUMMARY Six preterm infants with a persistent ductus arteriosus, who failed to improve with conventional medical management, received indomethacin in an attempt to close the duct pharmacologically. All infants weighed less than $1000 \mathrm{~g}$ when the drug was administered. All showed a transient response to indomethacin; however, no infant demonstrated a permanent response, even though 5 of the 6 received multiple doses. One of the patients developed a severe episode of anuria, uraemia, and gastrointestinal bleeding. Of the 6 infants, 3 underwent subsequent successful surgical ligation of the ductus. It is suggested that the extremely preterm infant may be a 'poor responder' to indomethacin. Since the side effects of indomethacin may be life-threatening, it may be wise to consider surgical ligation in lieu of indomethacin administration in these infants.

Management of persistent ductus arteriosus in preterm infants has been the subject of much research, discussion, and debate (Zachman et al., 1974; Neal et al., 1975; Thibeault et al., 1975). Until recently, if medical management failed, the only alternative was surgical ligation. In September 1976, the successful use of indomethacin, a potent prostaglandin synthetase inhibitor, was reported as promoting pharmacological closure of the persistent ductus arteriosus (Friedman et al., 1976; Heymann et al., 1976). The possibility of avoiding surgery in tiny preterm infants has led to the use of indomethacin in many institutions. However, in view of the possibility of side effects, several investigators have cautioned against widespread use of prostaglandin inhibitors before carefully designed clinical trials (Nadas, 1976; Friedman et al., 1977). Review of the data from 6 preterm infants who received the drug in the past 8 months forms the substance of this report.

\section{Subjects and methods}

PATIENT POPULATION

Between November 1976 and June 1977, preterm infants with persistent ductus arteriosus were

Received for publication 10 April 1978 considered as candidates for the administration of indomethacin according to the following guidelines.

All preterm infants with clinical features thought to be secondary to a persistent ductus arteriosus, with or without respiratory distress syndrome, received a trial of medical management for $\mathbf{4 8}$ hours. This included digitalis, diuretics, and careful fluid management. Failure of medical management was defined as continued severe congestive heart failure and/or inability to wean the infant from respiratory support (including constant positive airway pressure). In such cases, indomethacin was administered to those preterm infants who weighed less than $1000 \mathrm{~g}$. Preterm infants who weighed more than $1000 \mathrm{~g}$ underwent prompt surgical ligation of the persistent ductus arteriosus.

The diagnosis of persistent ductus arteriosus was based on typical physical, electrocardiographic, radiological, and echocardiographic findings.

Indomethacin was administered as a single dose of $0.3 \mathrm{mg} / \mathrm{kg}$ through a nasogastric tube. If there was no closure of the ductus within 48 hours (as manifested by disappearance of murmur, improvement in congestive heart failure, and discontinuance of respiratory support), surgical ligation was considered. If there was a response which was then followed by a relapse, a second dose of $0.3 \mathrm{mg} / \mathrm{kg}$ was administered since the persistent ductus 
arteriosus presumably was responsive to indomethacin.

\section{Results}

From November 1976 to June 1977, 6 infants, each weighing less than $1000 \mathrm{~g}$, received indomethacin. Clinical details are presented in the Table. The mean gestational age of the infants who received indomethacin was 29 weeks. The mean age at which the signs of persistent ductus arteriosus were first noted was 10 days, with a range of 5 to 30 days of age. Four of the 6 infants required respiratory assistance at the time the diagnosis of persistent ductus arteriosus was made. One infant required mechanical ventilation for his primary pulmonary disease and 3 required constant positive airway pressure for apnoea. All 6 infants were receiving maintenance digitalis, intermittent diuretics, and had their fluids restricted to 120 to $150 \mathrm{ml} / \mathrm{kg}$ per 24 hours. Two infants received aminophylline for treatment of recurrent apnoea within 48 hours of the administration of indomethacin.

All 6 infants exhibited the classical clinical signs of persistent ductus arteriosus, including typical murmur, gallop rhythm, full pulses, and hepatomegaly. Additionally, all infants had cardiomegaly and increased pulmonary vascularity on chest $x$-ray examination.

All infants had a transient beneficial response after the administration of indomethacin. This consisted of a decrease in the intensity of the murmur and of the peripheral pulses 6 to 12 hours after the administration of indomethacin. In all 6 infants, however, this response was short-lived, lasting approximately 12 hours. Treatment was repeated in 5 infants ( 5 doses in 1 case, and 3 in another), but in no case was permanent closure of the duct achieved with indomethacin.

Three of the 6 infants subsequently underwent surgical ligation of the duct. These 3 infants were in intractable congestive heart failure and, though critically ill, it was felt that the risk of congestive heart failure and its attendant problems outweighed the risk of surgery. All 3 infants survived surgery, had relatively benign postoperative courses, and showed complete resolution of congestive heart failure. Three infants did not undergo surgical ligation of the duct, as their congestive heart failure was relatively well controlled by medical management alone. Maintenance digitalis was continued at the time of discharge in 1 of these infants.

Side effects thought to be related to indomethacin were noted in case 6 . This patient was a preterm infant requiring constant positive airway pressure for apnoeic spells. She received indomethacin on the seventh day of life, $0.3 \mathrm{mg} / \mathrm{kg}$ by oroduodenal tube. Within 12 hours after this dose was administered, her murmur decreased slightly in intensity and her peripheral pulses decreased in amplitude. This effect lasted for approximately 18 hours, at which time her murmur increased in intensity and clinical signs of congestive heart failure increased. A repeat dose of indomethacin $(0.3 \mathrm{mg} / \mathrm{kg})$ was given by oroduodenal tube on the eighth day of life. Within 24 hours, she was anuric. Her congestive heart failure

Table

\begin{tabular}{|c|c|c|c|c|c|c|c|c|c|c|c|}
\hline \multirow[t]{2}{*}{ Case no. } & \multirow{2}{*}{$\begin{array}{l}\text { Gestational } \\
\text { age (20k) }\end{array}$} & \multirow{2}{*}{$\begin{array}{l}\text { Birthweight } \\
(\boldsymbol{g})\end{array}$} & \multirow{2}{*}{$\begin{array}{l}\text { Associated diagnosis } \\
\text { and support }\end{array}$} & \multirow{2}{*}{$\begin{array}{l}\text { Age } \\
P D A \\
\text { noted } \\
(d)\end{array}$} & \multicolumn{3}{|c|}{ Indomethacin } & \multirow[t]{2}{*}{ Response } & \multirow{2}{*}{$\begin{array}{l}P D A \\
\text { closure }\end{array}$} & \multirow{2}{*}{$\begin{array}{l}\text { Side } \\
\text { effects }\end{array}$} & \multirow[t]{2}{*}{ Outcome } \\
\hline & & & & & $\begin{array}{l}\text { Age } \\
\text { (d) }\end{array}$ & Route & $\begin{array}{l}\text { Dose } \\
(m g / k g)\end{array}$ & & & & \\
\hline 1 & 31 & 1000 & $\begin{array}{l}\text { CPAP and } \\
\text { aminophylline for } \\
\text { apnoea }\end{array}$ & 5 & $\begin{array}{l}13 \\
14\end{array}$ & Rectal & $\begin{array}{l}0 \cdot 3 \\
0 \cdot 12\end{array}$ & $\begin{array}{l}\text { Transient } \\
\text { None }\end{array}$ & $\begin{array}{l}\text { Spontaneous } \\
\text { at } 6 \mathrm{wk}\end{array}$ & None & Survived \\
\hline 2 & 28 & 810 & $\begin{array}{l}\text { CPAP and } \\
\text { aminophylline for } \\
\text { apnoea }\end{array}$ & 7 & 27 & $\begin{array}{l}\text { NG } \\
\text { tube }\end{array}$ & 0.3 & Transient & $\begin{array}{l}\text { Spontaneous } \\
\text { at } 6 \mathrm{wk}\end{array}$ & None & Survived \\
\hline 3 & 34 & 1050 & $\begin{array}{l}\text { Respiratory distress } \\
\text { syndrome and } \\
\text { apnoea }\end{array}$ & 6 & 11 & $\begin{array}{l}\text { NG } \\
\text { tube }\end{array}$ & $\begin{array}{l}0 \cdot 3 \\
0 \cdot 3\end{array}$ & $\begin{array}{l}\text { Transient } \\
\text { Transient }\end{array}$ & $\begin{array}{l}\text { No } \\
\text { Discharged } \\
\text { on digoxin }\end{array}$ & None & Survived \\
\hline 4 & 28 & 860 & Apnoea & 30 & $\begin{array}{l}30 \\
31 \\
32\end{array}$ & $\begin{array}{l}\text { NG } \\
\text { tube }\end{array}$ & $\begin{array}{l}0 \cdot 2 \\
0 \cdot 3 \\
0 \cdot 3\end{array}$ & $\begin{array}{l}\text { Transient } \\
\text { None } \\
\text { None }\end{array}$ & $\begin{array}{l}\text { Surgical } \\
\text { at } \\
35 \text { days }\end{array}$ & None & Survived \\
\hline 5 & 26 & 720 & $\begin{array}{l}\text { Respirator for } \\
\text { bronchopulmonary } \\
\text { dysplasia and } \\
\text { apnoea }\end{array}$ & 5 & $\begin{array}{l}30 \\
31 \\
33 \\
37 \\
42\end{array}$ & $\begin{array}{l}\text { NG } \\
\text { tube }\end{array}$ & $\begin{array}{l}0 \cdot 3 \\
0 \cdot 3 \\
0 \cdot 3 \\
0 \cdot 3 \\
0 \cdot 3\end{array}$ & $\begin{array}{l}\text { Transient } \\
\text { Transient } \\
\text { Transient } \\
\text { None } \\
\text { None }\end{array}$ & $\begin{array}{l}\text { Surgical } \\
\text { at } \\
56 \text { days }\end{array}$ & None & $\begin{array}{l}\text { Died day } \\
90 \text { from } \\
\text { necrotising } \\
\text { enterocolitis }\end{array}$ \\
\hline 6 & 28 & 890 & CPAP for apnoea & 5 & $\begin{array}{l}7 \\
8\end{array}$ & $\begin{array}{l}\text { NG } \\
\text { tube }\end{array}$ & $\begin{array}{l}0 \cdot 3 \\
0 \cdot 3\end{array}$ & $\begin{array}{l}\text { Transient } \\
\text { None }\end{array}$ & $\begin{array}{l}\text { Surgical } \\
\text { at } 12 \text { days }\end{array}$ & $\begin{array}{l}\text { Renal } \\
\text { failure } \\
\text { and GI } \\
\text { bleeding }\end{array}$ & Survived \\
\hline
\end{tabular}

PDA, persistent ductus arteriosus; NG, nasogastric; CPAP, constant positive airway pressure; GI, gastrointestinal. 
was exacerbated, and she required intubation and respirator support. Her creatinine rose to $362 \mu \mathrm{mol} / 1$ $(4.1 \mathrm{mg} / 100 \mathrm{ml})$ and her blood urea rose to 31.0 $\mathrm{mmol} / \mathrm{l}(87 \mathrm{mg} / 100 \mathrm{ml})$ on day 12 . Additionally, she developed bloody stools for 24 hours. On day 12 of life, she underwent surgical ligation of her duct with some resolution of her symptoms. Her urine output began to increase in approximately one week. She subsequently was weaned from the ventilator, and her creatinine returned to a normal value in 24 days. She was discharged with no medication. The indomethacin used in this child was tested ${ }^{1}$ and found to be the appropriate concentration as labelled by the University of Virginia Hospital Pharmacy. We found no error in the administration of this drug when reviewing hospital charts and nursing records.

\section{Discussion}

Published reports, with one exception (Neal et al., 1977), have been enthusiastic concerning the use of indomethacin for the pharmacological closure of the persistent ductus arteriosus. In the study by Friedman et al. (1976), 6 preterm infants with respiratory distress syndrome and persistent ductus arteriosus responded to a single dose of indomethacin. The dosage used in this study was 2.5 $\mathrm{mg} / \mathrm{kg}$ by mouth or $5 \mathrm{mg} / \mathrm{kg}$ per rectum. The only side effects noted were transient reduction in renal function in 2 infants. Heymann et al. (1976), using a much lower dosage of indomethacin $(0.1$ to $0.3 \mathrm{mg}$ / $\mathrm{kg}$ ), also felt indomethacin to be a valuable drug for producing constriction of the persistent ductus arteriosus. In their study, complete closure occurred within 24 hours in 5 infants given $0.3 \mathrm{mg} / \mathrm{kg}$. Two of these infants received 3 doses, and a raised serum creatinine was noted for 1 week. A very low dose, $0.1 \mathrm{mg} / \mathrm{kg}$, of indomethacin was used in 10 infants; ductal closure occurred within 24 to 30 hours in 8, and no alteration in renal function was noted. Heymann and Rudolph (1977) have subsequently published, in abstract form, data from an expanded trial, which apparently support their earlier findings, though it is unclear whether a 'response' was meant to indicate permanent or transient closure of the duct.

Our experience differs from these previously reported data, since none of our 6 preterm infants had a permanent response to indomethacin administration. Though we did observe transient responses, which were dramatic at times, this response was not sustained despite multiple doses. There are several possible reasons for the lack of permanent response in our infants. It has been suggested that there is

${ }^{1}$ Courtesy of Dr E. M. Cohen, Merck Sharp \& Dohme Research Laboratories, West Point, Penn. 19486, USA. inadequate development of the smooth muscle in the ductus arteriosus in the preterm infant (Danilowicz et al., 1966). Since all of our infants were premature (mean gestational age 29 weeks, with birthweights ranging from 720 to $1050 \mathrm{~g}$ ), it is quite possible that there was insufficient musculature to produce sustained constriction in response to either oxygen or indomethacin. The birthweights of all infants studied by Friedman et al. were over $1050 \mathrm{~g}$, with a mean weight of approximately $1500 \mathrm{~g}$. The group studied by Heymann et al., however, included 5 infants weighing less than $1000 \mathrm{~g}$. Four of these infants responded to indomethacin with permanent ductal closure, and, of these responders, only 1 required a repeat dose $(0 \cdot 1 \mathrm{mg} / \mathrm{kg} \times 2)$.

In previous studies the responsiveness of the duct to pharmacological closure has not been related to the postnatal age at which indomethacin was administered. These data are not available in Friedman's study. However, the mean age at which indomethacin was administered in Heymann's study was 10 days, with a range of 4 to 21 days. The mean age in our infants was 20 days, with a range from 7 to 30 days. Data from Olley et al. (1976) indicate that the ductus of preterm lambs will respond to blockers of prostaglandin synthesis at an early fetal age; however, there are no data concerning the responsiveness of the duct at particular postnatal ages in these same preterm animals. Since the ductus appears to lose sensitivity to oxygen as postnatal age increases (Nelson, 1976), it seems possible that the duct similarly might be less responsive to pharmacological agents later in the course of the infant's disease.

There is no comment in the previous papers as to whether or not the infants were receiving other medications, such as aminophylline. Many infants with persistent ductus arteriosus are also being treated for recurrent apnoea and may receive xanthines as part of such treatment (Shannon et al., 1975; Uauy et al., 1975). Two infants in our group had received aminophylline less than 48 hours before the administration of indomethacin. Theoretically, aminophylline might pharmacologically inhibit the effects of indomethacin on ductal closure. Aminophylline relaxes ductal tissue in vitro, presumably by increasing cyclic AMP (Kreil et al., 1973). It has been suggested, however, that the doses of aminophylline required to open the duct in vivo would be far in excesss of those doses currently in use for the treatment of apnoea (Soyka and Heese, 1975).

The lack of permanent response in our patient population is disconcerting as the use of indomethacin was initiated in an attempt to avoid surgery and its attendant risks in the tiny, preterm, critically ill 
infant. However, the risks of the drug also seem to be significant. Reported side effects of the drug include gastrointestinal toxicity, hepatitis, blood dyscrasias (Goodman and Gilman, 1970), and a deterioration in renal function (Friedman et al., 1976; Heymann et al., 1976). One of our infants (case 6) had a severe and potentially life-threatening episode of anuria and gastrointestinal bleeding temporally associated with the administration of indomethacin. Additionally, 3 of the infants in whom indomethacin was administered in an effort to avoid surgery ultimately required surgical ligation of the duct. Surgery was very well tolerated in all 3 patients, there were no complications, and the clinical response to surgical ligation was excellent.

Thus, in our experience, the ductus of the small preterm infant does not appear to respond well to indomethacin administration. Moreover, since the incidence of the side effects of indomethacin is unknown and the risk of surgical ligation appears relatively low, we feel it may be wise to consider early surgical ligation in preference to pharmacological treatment in these infants.

\section{References}

Danilowicz, D., Rudolph, A., and Hoffman, J. I. E. (1966). Delayed closure of the ductus arteriosus in premature infants. Pediatrics, 37, 74-78.

Friedman, W. F., Heymann, M. A., and Rudolph, A. M. (1977). Commentary: new thoughts on an old problempatent ductus arteriosus in the premature infant. Fournal of Pediatrics, 90, 338-340.

Friedman, W. F., Hirschklau, M. J., Printz, M. P., Pitlick, P. T., and Kirkpatrick, S. E. (1976). Pharmacologic closure of patent ductus arteriosus in the premature. New England Fournal of Medicine, 295, 526-529.

Goodman, L. S., and Gilman, A. (1970). The Pharmacologic Basis of Therapeutics, p. 338. Macmillan, London.

Heymann, M. A., and Rudolph, A. M. (1977). Evaluation of indomethacin in closure of the ductus arteriosus (abstract). Circulation, 55 and 56, Suppl. III, 192.
Heymann, M. A., Rudolph, A. M., and Silverman, N. H. (1976). Closure of the ductus arteriosus in premature infants by inhibition of prostaglandin synthesis. New England fournal of Medicine, 295, 530-533.

Kreil, E., Zapol, W., Sharp, G., Ayromlooi, J., Abrahams, G., and Ritz, R. (1973). Effects of cyclic AMP on isolated ductus arteriosus. Pediatric Research, 7, 300.

Nadas, A. S. (1976). Patent ductus revisited. New England Fournal of Medicine, 295, 563-565.

Neal, W. A., Bessinger, F. B., Jr., Hunt, C. E., and Lucas, R. V. (1975). Patent ductus arteriosus complicating respiratory distress syndrome. Fournal of Pediatrics, 86, 127131.

Neal, W. A., Kyle, J. M., and Mullet, M. D. (1977). Failure of indomethacin therapy to induce closure of patent ductus arteriosus in premature infants with respiratory distress syndrome. Fournal of Pediatrics, 91, 621-623.

Nelson, N. M. (1976). Respiration and circulation after birth. In The Physiology of the Newborn Infants, p. 150, ed C. A. Smith and N. M. Nelson. Charles C. Thomas, Springfield, Illinois.

Olley, P. M., White, E. P., Bodach, E., Heaton, J., and Coceani, F. (1976). The contractile response of the developing lamb ductus to ibuprofen (abstract). Circulation, $\mathbf{5 3}$ and 54, Suppl. II, 168.

Shannon, D. C., Gotay, I. M., Stein, M. C., Rogers, M. C., Todres, I. D., and Moylan, F. M. B. (1975). Prevention of apnoea and bradycardia in low birthweight infants. Pediatrics, 55, 589-594.

Soyka, L. F., and Heese, A. C. (1975). The use of xanthines in treating apnea of prematurity. Pediatrics, 56, 618.

Thibeault, D. W., Emmanouilides, G. C., Nelson, R. J., Lachman, R. S., Rosengart, R. M., and Oh, W. (1975). Patent ductus arteriosus complicating the respiratory distress syndrome in preterm infants. Fournal of Pediatrics, 87, 120-126.

Uauy, R., Shapiro, D. L., Smith, B., and Warshaw, J. B. (1975). Treatment of severe apnea in prematures with orally administered theophylline. Pediatrics, 55, 595-598.

Zachman, R. D., Steinmetz, G. P., Botham, R. J., Graven, S. N., and Ledbetter, M. K. (1974). Incidence and treatment of the patent ductus arteriosus in the ill premature neonate. American Heart fournal, 87, 697-703.

Requests for reprints to Dr Hallam H. Ivey, Department of Pediatrics, Box 386, University of Virginia Hospital, Charlottesville, Virginia 22901, USA. 